\title{
Comparative Studies on Growth, Flowering, Fruit Set and Yield of some Apple (Malus $\times$ domestica Borkh.) Cultivars under Mid Hill Conditions of Himachal Pradesh, India
}

\author{
Praveen Verma* and B.S. Thakur \\ Department of Fruit Science, Dr Y S Parmar University of Horticulture and Forestry, \\ Nauni, Solan-173230 (Himachal Pradesh) India \\ *Corresponding author
}

\section{Keywords}

Apple, Flowering, Fruit set, Growth characters, Yield

Article Info

Accepted:

20 January 2019

Available Online:

10 February 2019

\section{A B S T R A C T}

The study was carried out in the experimental orchard of the HRTS \& KVK, Kandaghat, Dr Yashwant Singh Parmar University of Horticulture and Forestry, Nauni, Solan (H.P.) during the year 2015-16. The experiment was laid out in Randomized Block Design with four replications. The observations were recorded on various parameters of tree growth, flowering, fruit set and yield. Among different cultivars Oregon Spur II recorded maximum increment in the trunk girth $(8.10 \%)$ and tree height $(22.37 \%)$. Tree spread $(1.74 \mathrm{~m})$ and tree volume $\left(2.13 \mathrm{~m}^{3}\right)$ was highest in Gale Gala while, minimum tree spread $(0.35 \mathrm{~m})$ and tree volume $\left(0.35 \mathrm{~m}^{3}\right)$ was recorded in cultivars Oregon Spur II and Scarlet Spur II respectively. Date of pink bud, first flowering and full bloom was early in cultivar Gale Gala (18 $8^{\text {th }}$ March, $20^{\text {th }}$ March and $27^{\text {th }}$ March) while, it was late in cultivar Gibson Golden $\left(24^{\text {th }}\right.$ March, $28^{\text {th }}$ March and $1^{\text {st }}$ April). The highest fruit set $(93.19 \%)$ was recorded in Golden Delicious and least in Early Red One (44.05 \%). Highest yield (9.91 $\mathrm{kg} / \mathrm{tree})$ was recorded in Gale Gala and lowest $(0.65 \mathrm{~kg} / \mathrm{tree})$ in Oregon Spur II.

\section{Introduction}

Apple (Malus $\times$ domestica Borkh.) is the most important temperate fruit crop of the north western Himalayan region. In India, the cultivation of apple is largely done in Jammu \& Kashmir, Himachal Pradesh and Uttrakhand. However, its cultivation is also done in Arunachal Pradesh, Nagaland, Meghalaya, Tamilnadu and Sikkim. In Himachal Pradesh, total area under apple cultivation is 109553 ha which accounts for the production of 625199 MT fruits (Anonymous, 2015). The most widely grown commercial cultivars of apple belong to delicious group, which constitutes $90 \%$ of the varieties grown in H.P. (Jindal et al., 1992). However, these cultivars have comparatively high chilling requirements, tendency towards irregular bearing, highly sensitive to temperature fluctuations, particularly during flowering and have comparatively low yield potential. The area under apple cultivation in sub-temperate region is shrinking and the 
situation is likely to worsen further in time to come particularly, in sub temperate areas because of non completion of chilling requirement, erratic rainfall and prolonged drought period during critical stages of growth and fruit development. It is emphasized upon that the sub-temperate region/ areas of the state shall regain its status of contributing sizable apple produce if new cultivars with low chilling requirements, high spur density and profused bearing potential are screened for their performance in such areas. In the recent past (1995-2000), large number of colour strains and varieties of apple were introduced in the state some of which have performed well under different agro climatic conditions. The best performing varieties were introduced at Horticulture Research and Training Station \& Krishi Vigyan Kendra, Kandaghat in Solan district of Himachal Pradesh during 2005. In view of its tree growth and flowering under the prevailing mid hill conditions of the state and the potential it offers for fruit diversification as well as in view of its yield, it was proposed to initiate the present study with the objective to study their growth, flowering, fruit set and yield traits.

\section{Materials and Methods}

The study was carried out in the experimental orchard of HRTS \& KVK, Kandaghat, Dr Yashwant Singh Parmar University of Horticulture and Forestry, Nauni, Solan (H.P.) during the year 2016. The cultivars undertaken for studies included Early Red One, Scarlet Spur II, Oregon Spur II, Golden Delicious, Granny Smith, Gale Gala and Gibson Golden. Four trees of each cultivar were selected randomly.

\section{Tree growth characters}

The growth parameters were recorded after the plants entered into dormancy and prior to pruning. The average trunk girth $(\mathrm{cm})$, tree height $(\mathrm{m})$, tree spread $(\mathrm{m})$ and annual shoot growth $(\mathrm{cm})$ was measured following standard procedure. The tree volume $\left(\mathrm{m}^{3}\right)$ of each replication was calculated from the data on height and spread measurements according to the formula suggested by Westwood (1993). Leaf area was measured with the help of an Automatic Leaf Area Meter (Licor Model 3100) and the values were expressed in square centimetre $\left(\mathrm{cm}^{2}\right)$.

\section{Flowering, fruit set and yield}

Observations pertaining to different phases of fruit bud development viz. date of bud swell, green tip, pink bud, first flowering, full bloom, last flowering and petal fall were recorded visually. The days from the date of first flowering to the date of last flowering was considered as the duration of flowering. Four branches of equal length $(30 \mathrm{~cm})$ on different aspect of the trees were tagged for counting total number of spurs and the mean of all was expressed as number of spurs per unit shoot length. Fruit set was recorded three weeks after petal fall and calculated as per the formula suggested by Westwood (1993). Fruit drop was calculated by subtracting the total number of fruits retained from total number of fruit set using the formula given by Westwood (1993). The yield of fruits under different treatments was recorded at the time of harvest by weighing the total fruits on top pan balance. The yield was expressed in kilograms per tree $(\mathrm{kg} / \mathrm{plant})$.

\section{Results and Discussion}

\section{Tree growth characters}

Among different cultivars Oregon Spur II recorded maximum increment in the trunk girth $(8.10 \%)$ while, Granny Smith recorded the minimum $(2.70 \%)$. Increment in tree height was recorded maximum in cultivar 
Oregon Spur II (22.37 \%) while; cultivar Gale Gala recorded the minimum $(7.96 \%)$. Tree spread $(1.74 \mathrm{~m})$ and tree volume $\left(2.13 \mathrm{~m}^{3}\right)$ was highest in Gale Gala while, minimum tree spread $(0.35 \mathrm{~m})$ and tree volume $(0.35$ $\mathrm{m}^{3}$ ) was recorded in cultivars Oregon Spur II and Scarlet Spur II respectively. Pruning weight was maximum in cultivar Gale Gala $(5.60 \mathrm{~kg})$ while, it was minimum in cultivar Oregon Spur II $(0.30 \mathrm{~kg})$ (Table 1$)$. Granny Smith and Gale Gala had spreading tree habit while, others had upright growth habit. Cultivars Scarlet Spur II and Oregon Spur II were exclusively spur bearers whereas; rest of the cultivars had mixed bearing habit i.e. on spurs and terminally on shoot. The cultivars Scarlet Spur II and Oregon Spur II were categorized as dwarf, while others were categorized as semi vigorous. Leaf area was recorded maximum in cultivar Granny Smith $\left(41.56 \mathrm{~cm}^{2}\right)$ while, cultivar Oregon Spur II recorded minimum $\left(30.89 \mathrm{~cm}^{2}\right)$ (Table 2$)$.

The performance of cultivars is a function of genetic make-up and environment. The results are in line with the findings of Sharma et al., (2004) who reported differences in growth parameters like tree height, spread, volume etc. Similarly, Bhat et al., (2006); Sharma (2011) and Hampson et al., (2009) also reported tree growth characters to vary from orchard to orchard. This variation could be due to the phenotypic characteristics of the cultivars, management practices and the site of plantation as well as age of the plants. Watkins and Smith, (1982) have categorized the tree habit, bearing habit and vigour on the basis of plant growth of different cultivars under study. Further, in the present study tree habit, bearing habit and vigour was described as per the apple descriptor published by IBPGR (Bioversity International) (1982).

\section{Flowering, fruit set and yield}

Date of pink bud, first flowering and full bloom was early in cultivar Gale Gala $\left(18^{\text {th }}\right.$
March, 20 ${ }^{\text {th }}$ March and $27^{\text {th }}$ March) while, it was late in cultivar Gibson Golden $\left(24^{\text {th }}\right.$ March, $28^{\text {th }}$ March and $1^{\text {st }}$ April). The longest duration of flowering was recorded in cultivar Granny Smith (20 days) followed by Golden Delicious (17 days) and the shortest flowering duration of eleven days was recorded in Scarlet Spur II.

Scarlet Spur II recorded the earliest $(08 / 04 / 2016)$ petal fall closely followed by Early Red One (09/04/2016) and was recorded as late as $19^{\text {th }}$ April in Granny Smith and $18^{\text {th }}$ April in Golden Delicious (Table 3). The highest fruit set $(93.19 \%)$ was in Golden Delicious and least in Early Red One (44.05 $\%$ ). Fruit drop was highest in Gale Gala $(62.34 \%)$ and lowest in Gibson Golden $(28.47 \%)$. Highest yield $(9.91 \mathrm{~kg} /$ tree $)$ was recorded in Gale Gala and lowest (0.65 $\mathrm{kg} /$ tree) in Oregon Spur II (Table 4).

The results of present study on flowering parameters are in accordance with the findings of Farooqui et al., (1986); Kumar and Verma (2001); Sharma (2002); Sharma et al., (2004); Singh et al., (2005) and Singh (2013) who reported variation in the time and duration of flowering while evaluating different apple cultivars under different growing conditions. They advocated that the differences in time and duration of flowering may be attributed to genetic make-up of cultivars and the prevailing climatic conditions in a particular site. The variation in fruit set has been reported by several workers and is mainly attributed to several factors like genetic make-up of a variety i.e. selfcompatible or self-incompatible, placement of pollinizer in an orchard and the prevailing climatic conditions at the time of flowering (Sharma, 2002; Sharma, 2011 and Singh, 2013). Similar observations have been recorded by several workers with varied range(s) of fruit drop (Iglesias, 1991 and Sharma, 2011 and Singh, 2013). 
Table.1 Tree growth characters of some apple cultivars-I

\begin{tabular}{|c|c|c|c|c|c|c|c|}
\hline \multirow[t]{2}{*}{ Name of cultivar } & \multirow{2}{*}{$\begin{array}{c}\text { Increment in } \\
\text { tree height } \\
(\%)\end{array}$} & \multirow{2}{*}{$\begin{array}{c}\text { Tree spread } \\
\text { (m) }\end{array}$} & \multirow{2}{*}{$\begin{array}{c}\text { Tree volume } \\
\left(\mathbf{m}^{3}\right)\end{array}$} & \multicolumn{2}{|c|}{ Annual shoot growth } & \multirow{2}{*}{$\begin{array}{c}\text { Increment in } \\
\text { trunk girth } \\
(\%)\end{array}$} & \multirow{2}{*}{$\begin{array}{c}\text { Pruning weight } \\
\text { (kg) }\end{array}$} \\
\hline & & & & 2015 & 2016 & & \\
\hline Early Red One & $11.31(3.50)$ & 1.36 & 3.28 & 44.69 & 40.75 & $4.10(2.24)$ & 0.56 \\
\hline Scarlet Spur II & $14.05(3.87)$ & 0.67 & 0.57 & 29.63 & 28.44 & $6.81(2.78)$ & 0.35 \\
\hline Oregon Spur II & $22.37(4.83)$ & 0.35 & 0.60 & 30.50 & 29.25 & $8.10(3.00)$ & 0.68 \\
\hline Golden Delicious & $15.21(4.02)$ & 0.96 & 1.29 & 35.94 & 38.09 & $4.70(2.38)$ & 0.51 \\
\hline Granny Smith & $9.84(3.28)$ & 1.45 & 3.56 & 37.88 & 38.49 & $2.70(1.90)$ & 1.47 \\
\hline Gale Gala & $7.96(2.99)$ & 1.74 & 5.60 & 48.31 & 41.85 & $3.21(2.05)$ & 2.13 \\
\hline Gibson Golden & $15.33(4.01)$ & 1.35 & 2.59 & 42.63 & 45.03 & $3.48(2.11)$ & 0.62 \\
\hline C.D. $(0.05)$ & 0.46 & 0.39 & 2.00 & 6.82 & 3.34 & 0.43 & 0.82 \\
\hline
\end{tabular}

Table.2 Tree growth characters of some apple cultivars-II

\begin{tabular}{|c|c|c|c|c|}
\hline $\begin{array}{l}\text { Name of } \\
\text { cultivar }\end{array}$ & $\begin{array}{l}\text { Tree } \\
\text { habit }\end{array}$ & Bearing habit & Tree vigour & $\begin{array}{l}\text { Leaf area } \\
\left(\mathrm{cm}^{2}\right)\end{array}$ \\
\hline Early Red One & Upright & $\begin{array}{c}\text { Spur and shoot } \\
\text { bearer }\end{array}$ & $\begin{array}{c}\text { Semi } \\
\text { vigorous }\end{array}$ & 40.64 \\
\hline Scarlet Spur II & Upright & Spur bearer & Dwarf & 34.30 \\
\hline Oregon Spur II & Upright & Spur bearer & Dwarf & 30.89 \\
\hline $\begin{array}{l}\text { Golden } \\
\text { Delicious }\end{array}$ & Upright & $\begin{array}{c}\text { Spur and shoot } \\
\text { bearer }\end{array}$ & $\begin{array}{c}\text { Semi } \\
\text { vigorous }\end{array}$ & 36.23 \\
\hline Granny Smith & Spreading & $\begin{array}{c}\text { Spur and shoot } \\
\text { bearer }\end{array}$ & $\begin{array}{c}\text { Semi } \\
\text { vigorous }\end{array}$ & 41.56 \\
\hline Gale Gala & Spreading & $\begin{array}{c}\text { Spur and shoot } \\
\text { bearer }\end{array}$ & $\begin{array}{c}\text { Semi } \\
\text { vigorous }\end{array}$ & 39.27 \\
\hline Gibson Golden & Upright & $\begin{array}{c}\text { Spur and shoot } \\
\text { bearer }\end{array}$ & $\begin{array}{c}\text { Semi } \\
\text { vigorous }\end{array}$ & 34.29 \\
\hline C.D. ${ }_{(0.05)}$ & & & & 1.85 \\
\hline
\end{tabular}


Table.3 Time and duration of flowering in some apple cultivars

\begin{tabular}{|c|c|c|c|c|c|c|c|c|}
\hline \multirow[t]{2}{*}{ Name of cultivar } & \multicolumn{3}{|c|}{ Stages of bud development (date) } & \multirow{2}{*}{$\begin{array}{c}\text { Date of } \\
\text { first } \\
\text { flowering }\end{array}$} & \multirow{2}{*}{$\begin{array}{l}\text { Date of full } \\
\text { bloom }\end{array}$} & \multirow{2}{*}{$\begin{array}{l}\text { Date of last } \\
\text { flowering }\end{array}$} & \multirow{2}{*}{$\begin{array}{c}\text { Duration of } \\
\text { flowering } \\
\text { (days) }\end{array}$} & \multirow{2}{*}{$\begin{array}{c}\text { Date of } \\
\text { petal fall }\end{array}$} \\
\hline & $\begin{array}{c}\text { Initiation of } \\
\text { bud swell }\end{array}$ & Green tip & Pink bud & & & & & \\
\hline Early Red One & 03-03-2016 & $16-03-2016$ & $22-03-2016$ & 24-03-2016 & $31-03-2016$ & 05-04-2016 & 12 & 09-04-2016 \\
\hline Scarlet Spur II & 03-03-2016 & $18-03-2016$ & $21-03-2016$ & $23-03-2016$ & $28-03-2016$ & 03-04-2016 & 11 & $08-04-2016$ \\
\hline Oregon Spur II & 05-03-2016 & 19-03-2016 & $22-03-2016$ & 24-03-2016 & 01-04-2016 & 07-04-2016 & 14 & $13-04-2016$ \\
\hline Golden Delicious & 08-03-2016 & $22-03-2016$ & 24-03-2016 & 27-03-2016 & 02-04-2016 & $13-04-2016$ & 17 & $18-04-2016$ \\
\hline Granny Smith & $05-03-2016$ & $20-03-2016$ & 21-03-2016 & 23-03-2016 & 29-03-2016 & 12-04-2016 & 20 & $19-04-2016$ \\
\hline Gale Gala & 06-03-2016 & $16-03-2016$ & $18-03-2016$ & 20-03-2016 & $27-03-2016$ & 03-04-2016 & 14 & 09-04-2016 \\
\hline Gibson Golden & 07-03-2016 & 21-03-2016 & 24-03-2016 & 28-03-2016 & 01-04-2016 & 11-04-2016 & 14 & $17-04-2016$ \\
\hline C.D. (0.05) & & & & & & & 2.06 & \\
\hline
\end{tabular}

Table.4 Spur density, fruit set, fruit drop and yield in some apple cultivars

\begin{tabular}{|l|c|c|c|c|}
\hline Name of cultivar & $\begin{array}{c}\text { Number of spurs } \\
\text { per unit shoot } \\
\text { length }\end{array}$ & $\begin{array}{c}\text { Fruit set } \\
(\mathbf{\%})\end{array}$ & $\begin{array}{c}\text { Fruit drop } \\
(\mathbf{\%})\end{array}$ & $\begin{array}{c}\text { Yield } \\
\text { (kg/tree) }\end{array}$ \\
\hline Early Red One & 5 & $44.05(41.56)$ & $36.97(37.43)$ & 2.51 \\
\hline Scarlet Spur II & 7 & $69.38(56.38)$ & $52.71(46.54)$ & 2.68 \\
\hline Oregon Spur II & 5 & $75.85(60.57)$ & $54.73(47.70)$ & 0.65 \\
\hline Golden Delicious & 4 & $93.19(74.90)$ & $35.87(36.75)$ & 2.29 \\
\hline Granny Smith & 4 & $87.13(69.06)$ & $55.05(47.88)$ & 7.76 \\
\hline Gale Gala & 5 & $81.69(64.64)$ & $62.34(52.12)$ & 9.91 \\
\hline Gibson Golden & 5 & $66.25(54.46)$ & $28.47(32.16)$ & 3.19 \\
\hline C.D. $(\mathbf{0 . 0 5})$ & 1.5 & 2.18 & 2.37 & 1.44 \\
\hline
\end{tabular}


The variation in fruit yield has been attributed by many factors like variety, soil conditions, rootstock, cultural practices etc. (Rathore, 1986; Kumar and Verma, 2001; and Sharma, 2011).

From the present work it is concluded that based on the growth and bearing habit, the cultivars can be grouped into two categories spur type (Scarlet Spur II and Oregon Spur II) and semi spur type (Early Red One, Golden Delicious, Granny Smith, Gale Gala and Gibson Golden). Cultivars Gale Gala and Granny Smith have good yielding potential. The cultivars Early Red One, Scarlet Spur II, Oregon Spur II and Gale Gala can be recommended for commercial cultivation under mid hill conditions of Himachal Pradesh because of their high fruit set and yield.

\section{Acknowledgements}

A special thanks to Dr YS Parmar University of Horticulture and Forestry, Nauni, Solan, (HP) for providing support and necessary facilities for this research work.

\section{References}

Anonymous. 2015. Horticulture development in Himachal Pradesh at a glance. www.hpagrisnet.gov.in

Bhat ZA, Wani MS and Wani WM. 2006. Evaluation of newly introduced apple cultivars for their vegetative characteristics. Annals of Biology22:4748.

Farooqui KD, Ahanger HU and Dalal MA. 1986. Genetic upgrading of apple. Progressive Horticulture 18:19-23.

Hampson CR, McNew R, Cline J, Embree C, Candstra J and Wilson K. 2009. Regional differences in performance of Canadian bred apple cultivars and implications for breeding. Canadian
Journal of Plant Science89:81-91.

Iglesias I. 1991. Performance studies of 16 apple cultivars in the experimental orchard at Seana-Bellpuig (Lleida). ITEA Production Vegetal87:67-96.

Jindal K K, Kakara B K, Sharma V K and Uppal D K. 1992. Evaluation of spur type and colour strains of apple. In: K C Chadda, D K Uppal, R N Pal, R P Awasthi and S A Ananda (eds.). Emerging trends in temperate fruit production in India. NHB Ted Commun, Gurgoan, India. pp. 39-94.

Kumar J and Verma HS. 2001. Performance of apple cultivars under low altitude conditions of Kullu Valley. Haryana Journal of Horticultural Sciences30:139-142.

Rathore DS. 1986. Preliminary evaluation of genetic resources of apple. In: Advances in Research on Temperate Fruits. (Chadha TR, Bhutani VP and Kaul JL eds). Proceedings of national symposium on 'Temperate Fruits', held from March 15-18, 1984 at Dr YS Parmar University of Horticulture and Forestry, Solan. pp. 3-6.

Sharma G, Chua GD and Sharma OC. 2004. Studies on evaluation and variability parameters in low chilling apples (Malus $\times$ domestica Borkh.). Acta Horticulturae662:157-162.

Sharma HR. 2011. Performance of Some Apple Cultivars under Sub Temperate Conditions of Himachal Pradesh (Malus $\times$ domestica Borkh.). M.Sc. Thesis. Department of Fruit Science, Dr YS Parmar University of Horticulture and Forestry, Solan. 53p.

Sharma Laxmi Kant. 2002. Performance of Some Spur Type Apple Cultivars on Clonal Rootstocks in Himachal Pradesh. M.Sc. Thesis. Department of Fruit Science, Dr YS Parmar University of Horticulture and Forestry, Solan. $61 \mathrm{p}$. 
Singh J. 2013. Studies on the performance of some newly introduced cultivars of apple (Malus $\times$ domestica Borkh.) under high hill conditions of Kinnaur (H.P.). M.Sc. Thesis. Department of Fruit Science, Dr YS Parmar University of Horticulture and Forestry, Solan. $56 \mathrm{p}$.

Singh SC, Pant KP, Dimri DC and Nautiyal MC. 2005. A note on flowering season and fruit characteristics on some apple cultivars. Acta Horticulturae696:49-51. Watkins R and Smith RA. 1982. Apple descriptors. International Board for Plant Genrtic Resources. IBPGR SECRETARIAT Rome. 49p.

Westwood MN. 1993. Plant efficiency: growth and yield measurements. In: Temperate Zone Pomology. WH Freeman and company (San Francisco). pp.275-282.

\section{How to cite this article:}

Praveen Verma and Thakur, B.S. 2019. Comparative Studies on Growth, Flowering, Fruit Set and Yield of Some Apple (Malus $\times$ domestica Borkh.) Cultivars under Mid Hill Conditions of Himachal Pradesh, India. Int.J.Curr.Microbiol.App.Sci. 8(02): 2710-2716. doi: https://doi.org/10.20546/ijcmas.2019.802.317 